\title{
Ring closure reactions of bicyclic prolinol and prolin ester enantiomers
}

\author{
Márta Palkó, ' Zsuzsa Molnár, ${ }^{\text {a } H e n r i ~ K i v e l a ̈,, ~ J a r i ~ S i n k k o n e n, ~}{ }^{c}$ Kalevi Pihlaja, \\ and Ferenc Fülöp ${ }^{\text {a,b* }}$ \\ ${ }^{a}$ Institute of Pharmaceutical Chemistry and ${ }^{b}$ Research Group of Stereochemistry of the \\ Hungarian Academy of Sciences, University of Szeged,H-6720 Szeged, Eötvös utca 6. Hungary \\ ${ }^{c}$ Department of Chemistry, University of Turku, FIN-20014 Turku \\ E-mail: fulop@pharm.u-szeged.hu
}

\section{Dedicated to Professor Henk van der Plas on the occasion of his $\mathbf{8 0}^{\text {th }}$ birthday}

\begin{abstract}
Starting from the of bicyclic proline ester, ethyl exo-2-azabicyclo[2.2.1] heptane-3-carboxylate $(+)-5$ several hydantoines and thiohydantoines were prepared by acidic ring closure of the corresponding urea or thiourea derivatives. Enantiomer (-)-5 was reduced to 2azanorbornylmethanol 12, which was transformed to 5,8-methanooxazolo- and thiazolo[3,4a]pyridine derivatives. The structures, stereochemistry and relative configurations of the synthesized compounds were proved by NMR.
\end{abstract}

Keywords: Bicyclic prolinol, enantioselective synthesis, epimerisation, ring closure, 1,3-heterocycles

\section{Introduction}

$\alpha$-Amino acids, both natural and unnatural, play a central part in biology and chemistry. ${ }^{1}$ They are fundamental constituents of proteins and other biologically important compounds and one of the most frequently used sources of chiral starting materials for organic synthesis. The synthesis and application of bicyclic $\alpha$-amino acids have received much attention of recent years. Many of these amino acids are carriers of pharmaceutical activities, ${ }^{2,3}$ and they have been used as building blocks for the synthesis of conformationally constrained peptides. ${ }^{4}$ Among them exo-2azabicyclo[2.2.1]heptane-3-carboxylic acid has received attention as a conformationally more rigid substitute for prolin in biologically active peptides ${ }^{5-7}$ and in the design of chiral ligands used in asymmetric catalysis. 8,9 
Ester derivatives of prolin exhibit interesting pharmacological effects: the L-proline ester of 2,6-diisopropylphenol (Propofol) derivative was synthetized by Trapini et al. This prolinate highly soluble and stable in water at physiological $\mathrm{pH}$ and rapidly hydrolyzed in plazma, could have potential as a water-soluble propofol prodrug for parenteral administration. ${ }^{10}$ Analogues of ( $N$-glyoxyl)propyl proline esters and chiral bicyclic proline esters have good binding affinity toward FKBP12, suggesting their potential therapeutic utility in treating degenerative disorders of the nervous system. ${ }^{11}$ Prolin esters and prolinol are widely used for the preparation of bicyclic oxazolidine, ${ }^{9,12-18}$ but its 2-azanorbornane derivatives ${ }^{19,20}$ have not been extensively investigated.

Amino ester 5 can be used as a starting substance for the preparation of other bifunctional compounds, e.g. amino acids, 1,2-aminoalcohols ${ }^{21,22}$ and 1,2-diamines ${ }^{23}$ and it has a few applications in the syntheses of other heterocycles. ${ }^{24,25}$

The synthesis and stereochemistry of bicyclic saturated heterocycles with condensed skeleton containing two heteroatoms have been the subject of our study for a long time. ${ }^{26}$ Previously several methods have been published for the preparation of cis- or trans-cycloalkane-fused 1,3heterocycles. ${ }^{26}$ As a continuation of this work our aim was to prepare enantiomeric bicyclic prolin esters (-)-5 and (+)-5 and prolinol derivatives and to synthesize some 2-azanorbornanefused heterocycles.

\section{Results and Discussion}

Amino ester (-)-5 and (+)-5 were prepared according to reported methods with small modifications. The syntheses of the key intermediate 4, is based on the finding that chiral imines with cyclopentadiene gives the [4+2]-cycloadduct. In spite of the reaction is highly exoselectivity, the separation of the major exo-isomer in the reaction from its diastereomers was accomplished by flash chromatography ${ }^{27,28}$. Multigram scale synthesis of the aza-Diels Alder adducts ethyl and methyl $(1 R, 3 R, 4 S)-2-[(1 S)$-1-phenylethyl]-azabicyclo[2.2.1]hept-5-ene-3carboxylate has been performed by Andersson et al. ${ }^{9}$ In this new protocol no purification of the intermediates, ethyl and methyl glyoxylate and the imine used for the Diels-Alder reaction, was necessary. The authors found that the methyl ester analogue of $\mathbf{4}$ could be easily recrystallized from pentane to afford diastereomerically pure adduct in $56 \%$ yield. The ethyl ester 4 have been separated from its diastereomers by column chromatography.

Our synthetic route to amino ester 5 is shown in Scheme 1. The synthesis started with oxidative cleavage of diethyl L-tartarate with sodium periodate, yielding the product, ethyl glyoxylate $\mathbf{1}$ in $1 \mathrm{~h}^{24}$ The aza-Diels-Alder reaction between $\mathbf{3}$ (derived from ethyl glyoxylate $\mathbf{1}$ and (S)-(-)-1-phenylethylamine 2) and cyclopentadiene, in the presence of trifluoroacetic acid and boron trifluoride diethyl etherate, have been performed in a one-step procedure. ${ }^{9}$ The crude hetero Diels-Alder adduct 4 could not crystallized from pentane, it was purified by column chromatography. Hydrogenation of the double bond of $\mathbf{4}$ and concomitant removal of the phenylethyl groups by hydrogenolysis in the presence of $\mathrm{Pd}(\mathrm{OH})_{2} / \mathrm{C}$ afforded amino ester (-)-5. 
The $\alpha$-amino acid ester $(+)-5$ was prepared from $(R)-(+)-1-$ phenylethylamine by the same method. The enantiomeric purity of amino esters 5 were checked (ee $>99 \%$ ) by chiral gas chromatography.

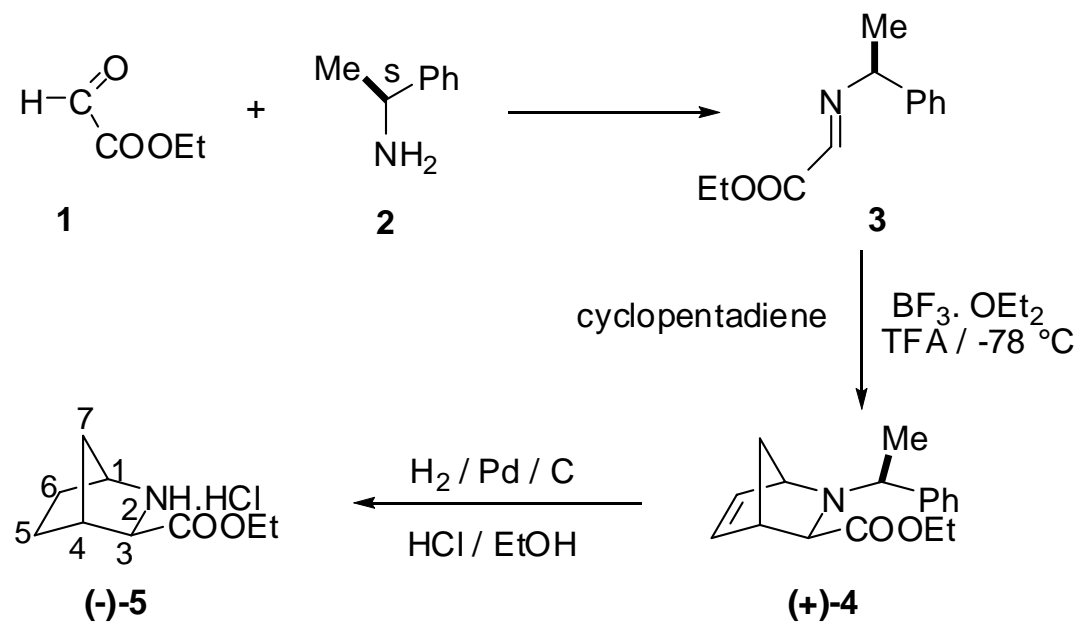

\section{Scheme 1}

Reaction of isothiocyanates with amino ester base (-)-5 resulted in the corresponding thioureas 6a-d. Thioureas 6a-d were cyclised with ethanolic hydrogen chloride or with aqueous hydrochloric acid, resulting in tricyclic 2-thioxo-imidazolidinone 7a-d. When 6a,b were boiled in acidic solution, partial isomerization took place resulting in exo-7a,b as the main products, which were separated from the endo-7a,b by column chromatography. The $m$-methoxy and $p$ chloro-substituted thioureas $\mathbf{7 c , d}$ resulted in only the exo-2-thioxo-imidazolidinone 7c,d, no formation of the endo isomer was observed (Scheme 2).

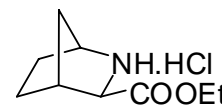

$(-)-5$

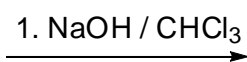

2. RNCS / toluene

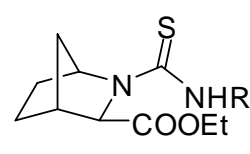

6a: $\mathrm{R}=\mathrm{Et}$

6b: $\mathrm{R}=\mathrm{C}_{6} \mathrm{H}_{4} \mathrm{OMe}(p)$

6c: $\mathrm{R}=\mathrm{C}_{6} \mathrm{H}_{4} \mathrm{OMe}(m)$

6d: $\mathrm{R}=\mathrm{C}_{6} \mathrm{H}_{4} \mathrm{Cl}(p)$

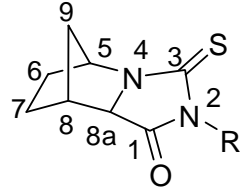

7a: $\mathrm{R}=\mathrm{Et}$ (major)

7 b: $\mathrm{R}=\mathrm{C}_{6} \mathrm{H}_{4} \mathrm{OMe}(p)$ (major)

7c: $\mathrm{R}=\mathrm{C}_{6} \mathrm{H}_{4} \mathrm{OMe}(m)$

7d: $\mathrm{R}=\mathrm{C}_{6} \mathrm{H}_{4} \mathrm{Cl}(p)$

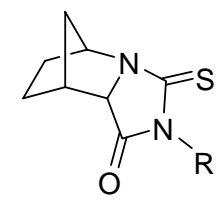

7a: $\mathrm{R}=\mathrm{Et}$ (minor)

7b: $\mathrm{R}=\mathrm{C}_{6} \mathrm{H}_{4} \mathrm{OMe}(p)$ (minor)

\section{Scheme 2}


When benzylisocyanate was reacted ester base (+)-5 the corresponding urea 8 was formed which was cyclised with ethanolic hydrogen chloride to hydantoin 9. Some related bicyclic hydantoins and thiohydantoins has been designed and synthesized in an enantiomeric manner by Salvati et al. ${ }^{29}$ Some of the compounds are potent antagonist to the androgen receptor. ${ }^{30-32}$

When amino ester base $(+)-5$ was reacted with 2 -chloroethyl isothiocyanate, $N$-thiazoline derivative $\mathbf{1 0}$ was formed. This intermediate was attempted to cyclise with ethanolic hydrogen chloride but the formation of the tetracyclic $\mathbf{1 1}$ was not observed.

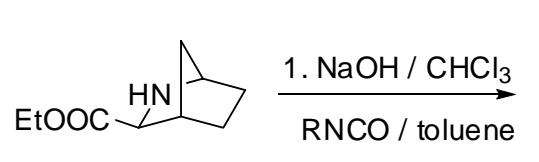

$(+)-5$

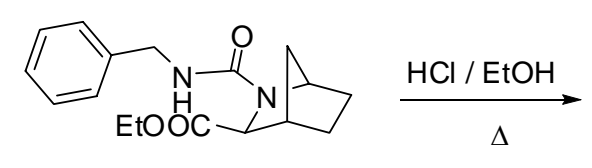

8

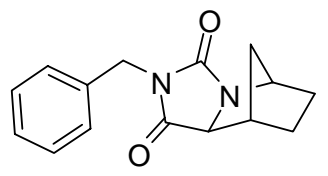

9

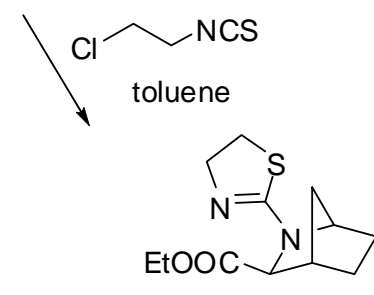

10

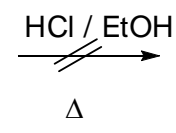

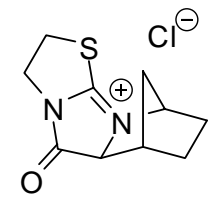

11

\section{Scheme 3}

The amino alcohol 12 was prepared from amino ester (-)-5 by $\mathrm{LiAlH}_{4}$ reduction. ${ }^{28} \mathbf{1 2}$ can be used as a chiral ligand for asymmetric transfer hydrogenation of ketones, ${ }^{28}$ and as a starting material for ring-closure reactions. ${ }^{19,20}$ The synthesis of heterocycle 14 started from the $p$ chlorophenyl isothiocyanate adduct of 12. Treatment of thiourea 13 with ethanolic hydrogen chloride under reflux provided thiazolidine 14 (Scheme 4). The possible Z-E isomerism of 14 was not investigated.

When amino alcohol 12 was condensed with $p$-nitrobenzaldehyde in methanol, the reaction reached completion within a few hours. After evaporation of the solvent the formation of two epimeric oxazolo[1,5-a]pyridine derivatives 15 was observed, of which the two epimers could be separated by crystallization. As the NMR spectra indicated, in the major epimer $15 \mathrm{H}-3$ locates on the same side as the bridge carbon C-9 of the norbornene skeleton. 


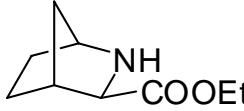

$(-)-5$

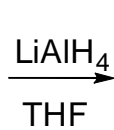

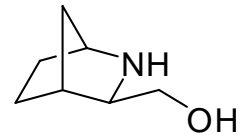

12

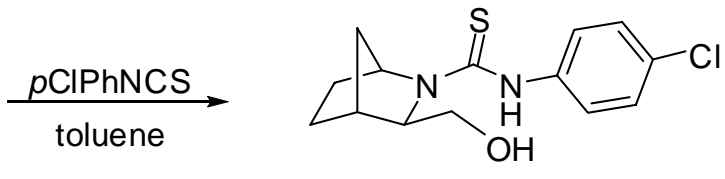

13
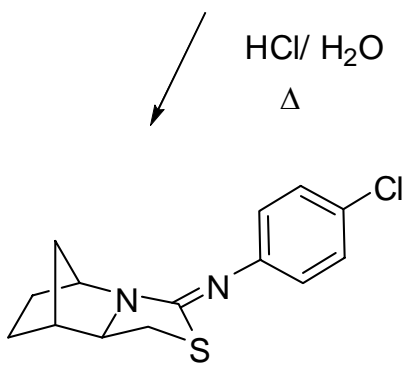

14

\section{Scheme 4}

The ${ }^{1} \mathrm{H}$ and ${ }^{13} \mathrm{C}$ NMR signals of $\mathbf{6 a - d}, \mathbf{7 a - d}, \mathbf{8 - 1 0}$, and 12-15 were assigned with the help of dqf-COSY, multiplicity-edited HSQC and HMBC experiments. The relative stereochemistry of the products was deduced mainly from NOESY experiments and proton-proton coupling constants. Many of the proton and carbon NMR signals were quite broad at $298 \mathrm{~K}$ in DMSO- $d_{6}$ (and even more so in $\mathrm{CDCl}_{3}$ ) due to some fast-intermediate chemical exchange processes such as hindered rotation of the substituents and because of the presence of small, unresolved protonproton couplings within the ${ }^{1} \mathrm{H}$ spin system of the 2-azanorbornane moiety. The reaction intermediates, e.g. compounds 6, generally displayed broader NMR lines than the ring-closed products. In the NMR spectra of each product, only one set of signals was observed indicating that any thermodynamically favoured dynamic processes were either relatively fast on the NMR time scale at the applied experimental conditions (in DMSO at $298 \mathrm{~K}$ at the field of a $500 \mathrm{MHz}$ instrument), or slow enough so that additional form(s) do not become clearly detectable in the sample within a few hours after dissolution in DMSO. However, many of the ${ }^{1} \mathrm{H}$ NMR signals were quite broad possibly due to some fast-intermediate chemical exchange process such as hindered rotation of the substituents, and due to the presence of small, unresolved proton-proton couplings within the ${ }^{1} \mathrm{H}$ spin system of the 2-azanorbornane moiety. In every case, the NMR spectra were consistent with the expected structures.

The ethoxycarbonyl substituent is in an exo position in the starting 2-azanorbornanes (-)-5 and (+)-5 yielding products that are exo substituted at $\mathrm{C}-8 \mathrm{a}$ if the configuration is retained during the synthesis. Compounds 6a-d, 7a,b (major products), 7c,d, 8, 9 and $\mathbf{1 5}$ (minor product) were indeed found to be exo substituted/fused, as deduced from the NOE cross peak between H-8a (or H-3 for the intermediates) and the endo-proton at C-7 (C-5 for the intermediates), and from the lack of such a cross peak between $\mathrm{H}-8 \mathrm{a}(\mathrm{H}-3)$ and the syn-proton at the methylene bridge carbon C-9 (C-7). Remarkably, the minor products of $\mathbf{7 a}$ and $\mathbf{7 b}$ did have the inverted configuration at 
$\mathrm{C}-8 \mathrm{a}$ resulting in and endo-fused imidazolidine ring, as proven by the NOE correlation between $\mathrm{H}-8 \mathrm{a}$ and H-9syn in the NOESY spectra of these compounds.

Product 15 exhibited two epimers with respect to the asymmetric carbon C-3, of which the major and the minor form could be separated pure by crystallisation. The major and minor epimers of 15 were again identified by their NOE correlations. For the major form a strong NOE is observed between protons H-9syn and H-3, as well as between H-5 and H-3. Therefore the major epimer is the one in which H-3 locates on the same side as the bridge carbon C-9 of the norbornene skeleton. In case of the minor epimer of $\mathbf{1 5}$ the ortho protons of the $p$-nitrophenyl group (7.70 ppm) displayed and NOE correlation with H-9syn (1.47 ppm) whereas H-3 (5.34 ppm) was NOE correlated with $\mathrm{H}-8 \mathrm{a}(3.28 \mathrm{ppm})$. This establishes that in the minor epimer the aryl group is on the same face of the tricyclic skeleton as the methylene bridge.

\section{Experimental Section}

General Procedures. Melting points were determined with a Koffler apparatus and are not corrected. Merck Kieselgel 60F254 plates were used for TLC: the eluent was toluene-MeOH 4:1. Column chromatography was performed on silica gel (Merck 60, 70-230 mesh). NMR-spectra were acquired using Bruker Avance 400 and 500 spectrometers (equipped with BBI-5mmZgrad-ATM and BBO-5mm-Zgrad probes) operating at 399.75 and $500.13 \mathrm{MHz}$ for ${ }^{1} \mathrm{H}$ and 100.53 and $125.77 \mathrm{MHz}$ for ${ }^{13} \mathrm{C}$, respectively. No sample spinning was used. DMSO- $d_{6}$ was used as solvent with tetramethylsilane (TMS) as an internal standard $\left(\delta_{\mathrm{TMS}}=0.00 \mathrm{ppm}\right.$ for both ${ }^{1} \mathrm{H}$ and ${ }^{13} \mathrm{C}$ ), and the probe temperature was set at $298 \mathrm{~K}$. Spectra were processed by a PC with Windows XP operating system and XWin-NMR software. ${ }^{1} \mathrm{H}$ NMR spectra were acquired with single-pulse excitation using a $30^{\circ}$ flip angle, $2.3 \mu \mathrm{s}$ (BBI) or $3.0 \mu \mathrm{s}$ (BBO) pulse width, 10.3 $\mathrm{kHz}$ spectral width and $3.17 \mathrm{~s}$ acquisition time, and processed with $0.3 \mathrm{~Hz}$ exponential weighing prior to Fourier transform. ${ }^{13} \mathrm{C}$ NMR spectra were acquired with single-pulse excitation and broadband proton decoupling (waltz-16) using a $30^{\circ}$ flip angle, $4.2 \mu \mathrm{s}(\mathrm{BBI})$ or $2.3 \mu \mathrm{s}$ (BBO) pulse width, $30.0 \mathrm{kHz}$ spectral width and $1.09 \mathrm{~s}$ acquisition time, and processed with $1.0 \mathrm{~Hz}$ exponential weighing prior to Fourier transform. The gradient-selected dqf-COSY, NOESY, multiplicity-edited HSQC and HMBC 2D NMR experiments were acquired using vendorprovided pulse programs (cosygpmfqf, noesygpph, hsqcedetgpsisp2 and hmbcgplpndqf, respectively). The NOESY mixing time was set at $0.3 \mathrm{~s}$, and the HSQC and HMBC experiments were optimized for a one-bond $\mathrm{C}, \mathrm{H}$ coupling constant of $145 \mathrm{~Hz}$ and long-range coupling constants of $10 \mathrm{~Hz}$.

The electron ionization (EI) mass spectra were recorded on a VG ZABSpec mass spectrometer (VG Analytical, Division of Fisons, Manchester, UK), that was equipped with Opus V3.3X program package (Fisons Instruments, Manchester, UK). The ionization energy was $70 \mathrm{eV}$ and source temperature $160{ }^{\circ} \mathrm{C}$. Small samples dissolved in methanol were placed into a quartz capillary tube and methanol was evaporated with hot air. Thereafter the sample was taken into 
the ionization chamber via the solid insertion probe. Perfluorokerosine (PFK) was used for calibration of the mass scale. The elemental compositions of the molecular ions were determined by peak matching (10\% valley definition) using 10000 resolution.

Cyclopentadiene was obtained from its dimer by heating at $200{ }^{\circ} \mathrm{C}$. The ee values of the esters (+)-5 and (-)-5 were determined by gas chromatography on a Chrompack CP Chiracel-Dex CB column $(25 \mathrm{~m})$. Amino esters (-)-5 and (+)-5 were derivatised with acetic anhydride in the presence of 4-dimethylaminopyridine (DMAP) and pyridine (P) before the gas chromatographic analysis. To a solution of ester 5 (1 mg in $\left.0,1 \mathrm{~mL} \mathrm{CH}_{2} \mathrm{Cl}_{2}\right) 15 \mu \mathrm{L}$ DMAP/P (1:9) and $15 \mu \mathrm{L}$ $\mathrm{Ac}_{2} \mathrm{O}$ was added; $\left[80{ }^{\circ} \mathrm{C}\right.$ for $5 \mathrm{~min} \rightarrow 130{ }^{\circ} \mathrm{C}$ (rate of temperature rise $20{ }^{\circ} \mathrm{C} / \mathrm{min} ; 70 \mathrm{kPa}$, carrier gas $\mathrm{N}_{2}, \mathrm{~T}_{\text {inj. }} 250{ }^{\circ} \mathrm{C}, \mathrm{T}_{\text {det. }} 270{ }^{\circ} \mathrm{C}$ ), retention times (min): (-)-5: 12.42; (+)-5: 12.71]. Optical rotations were measured with a Perkin-Elmer 341 polarimeter.

\section{Ethyl (1S,3R,4R)-2-azabicyclo[2.2.1]heptane-3-carboxylate hydrochloride (-)-5 and ethyl (1R,3S,4S)-2-azabicyclo[2.2.1] heptane-3-carboxylate hydrochloride (+)-5.}

To a magnetically stirred aqueous solution of diethyl L-(+)-tartrate $(6.8 \mathrm{~g}, 33 \mathrm{mmol}$ in $50 \mathrm{~mL})$, one equivalent of $\mathrm{NaOI}_{4}$ was added at $0{ }^{\circ} \mathrm{C}$ during $15 \mathrm{~min}$. The mixture was stirred for one hour at the same temperature and evaporated. The residue was dissolved in $\mathrm{CH}_{2} \mathrm{Cl}_{2}$, dried $\left(\mathrm{Na}_{2} \mathrm{SO}_{4}\right)$ and evaporated. The produced ethyl glyoxylate $(5.1 \mathrm{~g} 50 \mathrm{mmol})$ was dissolved in $\mathrm{CH}_{2} \mathrm{Cl}_{2}$, molecular sieves ( $2 \mathrm{~g}, 4 \AA \hat{\text { }})$ were added under argon atmosphere and the mixture was cooled to 4 ${ }^{\circ} \mathrm{C}$. (S)-(-)-1-Phenylethylamine $(6.2 \mathrm{~g}, 51 \mathrm{mmol})$ was added and the mixture was stirred for $1 \mathrm{~h}$. The water bath was replaced with a dry ice/isopropanol bath with an external cooler and the reaction mixture was cooled to $-78{ }^{\circ} \mathrm{C}$. A solution of imine 3 was sequentially treated with $\mathrm{CF}_{3} \mathrm{COOH}(4 \mathrm{~mL}, 52 \mathrm{mmol}), \mathrm{BF}_{3} . \mathrm{Et}_{2} \mathrm{O}(6.6 \mathrm{~mL}, 52 \mathrm{mmol})$ and with freshly distilled cyclopentadiene $(5.1 \mathrm{~mL})$. When the addition was complete the reaction mixture was stirred for 8 $\mathrm{h}$ at $-75{ }^{\circ} \mathrm{C}$ and the mixture was thereafter allowed to warm to ambient temperature. When the room temperature was reached the mixture, it was poured into a saturated aqueous solution of $\mathrm{Na}_{2} \mathrm{CO}_{3}$. The resulting mixture was stirred for $2 \mathrm{~h}$ and filtered then through a pad of Celite and the residue washed with $\mathrm{CH}_{2} \mathrm{Cl}_{2}(2 \times 50 \mathrm{~mL})$. The layers were separated and the aqueous phase extracted with $\mathrm{CH}_{2} \mathrm{Cl}_{2}(2 \times 50 \mathrm{~mL})$. The organic phases was dried $\left(\mathrm{MgSO}_{4}\right)$, and evaporated to give the crude Diels-Alder adduct 4 , which was purified by column chromatography on silica gel using $n$-hexane/ethyl acetate $(9: 1)(6.86 \mathrm{~g}, 52 \%)[\alpha]_{D}^{25}=+86.0$ (c 1, MeOH). The major diastereomer 4 (6 g, $22 \mathrm{mmol})$ was hydrogenated over $\mathrm{Pd}(\mathrm{OH})_{2} / \mathrm{C}(5 \%, 0.5 \mathrm{~g})$ in abs. EtOH $(100$ $\mathrm{mL}$ ) at 50 bar initial $\mathrm{H}_{2}$ pressure. After 3 days the mixture was filtered off and the residue washed with abs. EtOH. To the filtrate ethanolic $\mathrm{HCl}(5 \mathrm{~mL}, 22 \%)$ was added and the mixture was then evaporated. The residue was crystallized with $\mathrm{Et}_{2} \mathrm{O}$ and recrystallized from $\mathrm{EtOH} / \mathrm{Et}_{2} \mathrm{O}$. (-)-5: White crystals mp $148-149{ }^{\circ} \mathrm{C}$ yield $3.0 \mathrm{~g},(66 \%)$ Lit $\mathrm{mp}^{28}: 153-154{ }^{\circ} \mathrm{C}[\alpha]_{D}^{25}=-15.9$ (c 1 , $\mathrm{MeOH})$ Lit $[\alpha]_{D}^{25}=-16.3(\mathrm{c} 1, \mathrm{MeOH})^{27}$ The $(+)-5$ amino ester hydrochloride was prepared from $(R)-(+)-1$-phenylethylamine by the same method. White crystals $\mathrm{mp} 148-149{ }^{\circ} \mathrm{C}$ Lit $\mathrm{mp}^{28} 153-$ $154{ }^{\circ} \mathrm{C}[\alpha]_{D}^{25}=+18.8(\mathrm{c} 1, \mathrm{MeOH})$ Lit $[\alpha]_{D}^{25}=+16.2(\mathrm{c} 1, \mathrm{MeOH})^{28}{ }^{1} \mathrm{H} \mathrm{NMR}\left(\mathrm{DMSO}-\mathrm{d}_{6}\right) \delta(\mathrm{ppm})$ : $1.25\left(3 \mathrm{H}, \mathrm{t}, J=7.1 \mathrm{~Hz}, \mathrm{OCH}_{2} \mathrm{CH}_{3}\right.$ ) $), 1.54-1.70(5 \mathrm{H}, \mathrm{m}, \mathrm{H}-5, \mathrm{H}-6, \mathrm{H}-7), 1.93$ (1H, brt, $J=10.3$ 
Hz, H-6), 2.87 (1H, brd, J = 3.4 Hz, H-4), 4.02 (1H, s, H-3), 4.05 (1H, brs, H-1), 4.23 (2H, m, $\left.\mathrm{OCH}_{2} \mathrm{CH}_{3}\right) .{ }^{13} \mathrm{C}$ NMR (DMSO-d 6$) \delta(\mathrm{ppm}): 13.8\left(\mathrm{OCH}_{2} \mathrm{CH}_{3}\right), 24.3(\mathrm{C}-6), 26.1(\mathrm{C}-7), 34.7(\mathrm{C}-5)$, 39.8 (C-4), 58.2 (C-1), $61.6(\mathrm{C}-3), 62.3\left(\mathrm{OCH}_{2} \mathrm{CH}_{3}\right), 168.3(\mathrm{C}=\mathrm{O}) . \mathrm{M}^{+\bullet}(6) \mathrm{C}_{9} \mathrm{H}_{15} \mathrm{NO}_{2}^{+\bullet} \mathrm{Calcd}^{+}$ 169.1103 Obsd 169.1104 Other ions $\mathrm{m} / \mathrm{z}(\%)$ : 96(100), 68(66), 67(11), 41(11)

\section{General procedure the synthesis of urea and thiourea derivatives 6a-d and 8}

One equivalent of the corresponding isothiocyanate or isocyanate was added to $0.5 \mathrm{~g}$ (2.96 mmol) (+)-5 or (-)-5 bases, dissolved in $20 \mathrm{~mL}$ toluene. The mixture was stirred overnight then was evaporated, $n$-hexane was added, and the crystalline products $\mathbf{6 b}$-d and $\mathbf{8}$ were filtered off and recrystallized. The oily $\mathbf{6 a}$ was purified by column chromatography.

Ethyl (1S,3R,4R)-2-ethylthiocarbamoyl-2-azabicyclo[2.2.1]heptane-3-carboxylate (6a). Oil, $(n$-hexane/EtOAc $=3: 1)$; yield $0.48 \mathrm{~g},(64 \%) ;[\alpha]_{D}^{25}=+135.7(\mathrm{c} 1, \mathrm{MeOH}){ }^{1} \mathrm{H}$ NMR $\left(\mathrm{DMSO}-\mathrm{d}_{6}\right)$ $\delta(\mathrm{ppm}): 1.08\left(3 \mathrm{H}, \mathrm{t}, J=6.9 \mathrm{~Hz}, \mathrm{NCH}_{2} \mathrm{CH}_{3}\right), 1.18\left(3 \mathrm{H}, \mathrm{t}, J=7.0 \mathrm{~Hz}, \mathrm{OCH}_{2} \mathrm{CH}_{3}\right.$ ) $), 1.39-1.44(2 \mathrm{H}$, m, H-5, H-7), 1.49 (1H, brm, H-6), 1.60 (1H, brm, H-6), 1.72 (1H, m, H-5), 1.92 (1H, brm, H-7), $2.54(1 \mathrm{H}$, brs, $\mathrm{H}-4), 3.46\left(2 \mathrm{H}\right.$, brm, $\left.\mathrm{NCH}_{2} \mathrm{CH}_{3}\right), 4.07\left(2 \mathrm{H}\right.$, brq, $\left.J=7.0 \mathrm{~Hz}, \mathrm{OCH}_{2} \mathrm{CH}_{3}\right), 4.22(1 \mathrm{H}$, brs, H-3), 4.55 (1H, brs, H-1), 7.61 (1H, brs, NH). $\left.{ }^{13} \mathrm{C} \mathrm{NMR} \mathrm{(DMSO-d} 6\right) \delta(\mathrm{ppm}): 14.0$ $\left(\mathrm{OCH}_{2} \mathrm{CH}_{3}\right), 14.5\left(\mathrm{NCH}_{2} \mathrm{CH}_{3}\right), 27.2(\mathrm{C}-5), 28.8(\mathrm{C}-6), 35.2(\mathrm{C}-7), 39.5\left(\mathrm{NCH}_{2} \mathrm{CH}_{3}\right), 40.9(\mathrm{C}-4)$, $57.3(\mathrm{C}-1), 60.0\left(\mathrm{OCH}_{2} \mathrm{CH}_{3}\right), 69.0(\mathrm{C}-3), 170.0(\mathrm{C}=\mathrm{O}), 178.3(\mathrm{C}=\mathrm{S}) . \mathrm{M}^{+\bullet}(100) \mathrm{C}_{12} \mathrm{H}_{20} \mathrm{~N}_{2} \mathrm{O}_{2} \mathrm{~S}^{+\bullet}$ Calcd 256.1246 Obsd 256.1256 Oher ions $\mathrm{m} / \mathrm{z}(\%)$ : 210(14), 183(16), 169(15), 144(13), 140(29), 96(65), 95(12), 68(45), 67(10), 60(15), 44(2)

Ethyl (1S,3R,4R)-2-(4-methoxyphenylthiocarbamoyl)-2-azabicyclo[2.2.1]heptane-3-carboxylate (6b). White crystals, mp $185-186^{\circ} \mathrm{C}$ (EtOAc); yield $0.63 \mathrm{~g},(64 \%) ;[\alpha]_{D}^{25}=+80.3$ (c 0.5 , EtOH) ${ }^{1} \mathrm{H}$ NMR (DMSO-d $) \delta(p p m): 1.19\left(3 \mathrm{H}, \mathrm{t}, J=7.1 \mathrm{~Hz}, \mathrm{OCH}_{2} \mathrm{CH}_{3}\right.$, $), 1.48(1 \mathrm{H}, \mathrm{Br} \mathrm{d}, J=$ $9.9 \mathrm{~Hz}, \mathrm{H}-7 a n t i), 1.51(1 \mathrm{H}, \mathrm{m}, \mathrm{H}-5 e n d o), 1.63-1.73$ (2H, m, H-6exo, H-6endo), 1.77 (1H, m, H5exo), 2.02 (1H, m, H-7syn), 2.61 (1H, brs, H-4), $3.74\left(3 \mathrm{H}, \mathrm{s}, p-\mathrm{OCH}_{3}\right) 4.08(2 \mathrm{H}, \mathrm{q}, \mathrm{J}=7.0 \mathrm{~Hz}$, $\left.\mathrm{OCH}_{2} \mathrm{CH}_{3}\right), 4.31$ (1H, brs, H-3), 4.82 (1H, brs, H-1), $6.87(2 \mathrm{H}, \mathrm{m}, \mathrm{m}-\mathrm{Ar}), 7.22$ (2H, m, o-Ar), $9.16(1 \mathrm{H}$, brs, $\mathrm{NH}) .{ }^{13} \mathrm{C}$ NMR $\left(\mathrm{DMSO}_{6}\right) \delta(\mathrm{ppm}): 14.0\left(\mathrm{OCH}_{2} \mathrm{CH}_{3}\right), 27.2(\mathrm{C}-5), 29.2(\mathrm{C}-6)$, 35.4 (C-7), $41.0(\mathrm{C}-4), 55.1\left(p-\mathrm{OCH}_{3}\right), 58.4(\mathrm{C}-1), 60.1\left(\mathrm{OCH}_{2} \mathrm{CH}_{3}\right), 69.4(\mathrm{C}-3), 113.1(\mathrm{~m}-\mathrm{Ar})$, 127.6 (o-Ar), 1331. (i-Ar), 156.5 (p-Ar), $169.8(\mathrm{C}=\mathrm{O}), 178,5(\mathrm{C}=\mathrm{S}) . \mathrm{M}^{+\bullet}(87) \mathrm{C}_{17} \mathrm{H}_{22} \mathrm{~N}_{2} \mathrm{O}_{3} \mathrm{~S}^{+\bullet}$ Calcd 334.1351; Obsd 334.1353.Other ions $\mathrm{m} / \mathrm{z}$ (\%): 301(13), 289(12), 288(40), 212(30), 195(11), 184(11), 167(14), 166(20), 165(100), 150 (26), 140 (51), 138(14), 125(11.5), 123(26), 122(22), 108(18), 96(90), 95(11), 79(29), 68(41), 67(17), 41(12)

Ethyl (1S,3R,4R)-2-(3-methoxyphenylthiocarbamoyl)-2-azabicyclo[2.2.1]heptane-3-carboxylate (6c). White crystals, mp 102-104 ${ }^{\circ} \mathrm{C}$ (EtOAc); yield $0.73 \mathrm{~g},(74 \%) ;[\alpha]_{D}^{25}=+82.4$ (c 0.5 , $\mathrm{MeOH}){ }^{1} \mathrm{H}$ NMR (DMSO-d $) \delta(\mathrm{ppm}):{ }^{1} \mathrm{H}$ NMR $\left(\mathrm{DMSO}_{6}\right) \delta(\mathrm{ppm}): 1.19(3 \mathrm{H}, \mathrm{t}, J=7.1 \mathrm{~Hz}$, $\left.\mathrm{OCH}_{2} \mathrm{CH}_{3}\right), 1.48(1 \mathrm{H}$, brd, $J=9.9 \mathrm{~Hz}, \mathrm{H}-7$ anti), $1.51(1 \mathrm{H}, \mathrm{m}, \mathrm{H}-5 e n d o), 1.62-1.73$ (2H, m, H6exo, H-6endo), 1.78 (1H, m, H-5exo), 2.02 (1H, m, H-7syn), $2.62(1 \mathrm{H}$, brs, H-4), 3.73 (3H, s, $\left.m-\mathrm{OCH}_{3}\right), 4.09\left(2 \mathrm{H}, \mathrm{q}, J=7.0 \mathrm{~Hz}, \mathrm{OCH}_{2} \mathrm{CH}_{3}\right), 4.33$ (1H, brs, H-3), 4.86 (1H, brs, H-1), $6.701 \mathrm{H}$, m, p-Ar), 6.98 (1H, m, o'-Ar), 7.04 (1H, brs, o-Ar), 7.20 (1H, t, J = 8.1 Hz, m'-Ar), 9.24 (1H, 
brs, NH). ${ }^{13} \mathrm{C}$ NMR (DMSO-d $) \delta(p p m): 14.0\left(\mathrm{OCH}_{2} \mathrm{CH}_{3}\right), 27.2$ (C-5), 29.4 (C-6), 35.4 (C-7), 41.0 (C-4), $55.0\left(m-\mathrm{OCH}_{3}\right), 58.8(\mathrm{C}-1), 60.1\left(\mathrm{OCH}_{2} \mathrm{CH}_{3}\right), 69.3$ (C-3), 110.1 (o-Ar), 111.1 (p-Ar), 117.6 (o'-Ar), 128.5 (m’-Ar), 141.3 (i-Ar), 158.8 (m-Ar), 169.7 (C=O), 177.9 (C=S). M ${ }^{+\bullet}(100)$ $\mathrm{C}_{17} \mathrm{H}_{22} \mathrm{~N}_{2} \mathrm{O}_{3} \mathrm{~S}^{+\bullet}$ Calcd 334.1351; Obsd 334.1356. Other ions $\mathrm{m} / \mathrm{z}(\%): 333(15), 301(10), 289(7)$, 288(9), 261(7), 212(20), 195(8), 184(5.5), 169(10), 166(14.5), 165(23), 140(17), 138(6), 123(15), 96(60), 95(7), 79(14), 77(13), 68(29), 67(9), 41(7)

Ethyl (1S,3R,4R)-2-(4-chlorophenylthiocarbamoyl)-2-azabicyclo[2.2.1]heptane-3-carboxylate (6d). White crystals, mp 60-62 ${ }^{\circ} \mathrm{C}$ (EtOAc); yield $0.66 \mathrm{~g},\left(68 \%\right.$ ); $[\alpha]_{D}^{25}=+92.9$ (c 0.5 , $\mathrm{MeOH}){ }^{1} \mathrm{H}$ NMR (DMSO-d $) \delta(\mathrm{ppm}): 1.19\left(3 \mathrm{H}, \mathrm{t}, J=7.1 \mathrm{~Hz}, \mathrm{OCH}_{2} \mathrm{CH}_{3}\right), 1.49(1 \mathrm{H}, \mathrm{brd}, J=$ 10.0 Hz, H-7anti), 1.51 (1H, m, H-5endo), 1.62-1.73 (2H, m, H-6exo, H-6endo), 1.78 (1H, m, H5exo), 2.03 (1H, m, H-7syn), 2.63 (1H, br s, H-4), $4.09\left(2 \mathrm{H}, \mathrm{q}, J=7.0 \mathrm{~Hz}, \mathrm{OCH}_{2} \mathrm{CH}_{3}\right), 4.31$ (1H, brs, H-3), 4.86 (1H, brs, H-1), 7.35 (2H, m, m-Ar), 7.42 (2H, m, o-Ar), 9.35 (1H, brs, NH). ${ }^{13} \mathrm{C}$ NMR (DMSO-d 6 ) $\delta(\mathrm{ppm}): 14.0\left(\mathrm{OCH}_{2} \mathrm{CH}_{3}\right), 27.1$ (C-5), 29.4 (C-6), 35.4 (C-7), 41.0 (C-4), 58.9 (C-1), $60.2\left(\mathrm{OCH}_{2} \mathrm{CH}_{3}\right), 69.4$ (C-3), 127.2 (o-Ar), 127.7 (m-Ar), 128.5 (p-Ar), 139.2 (i-Ar), $169.6(\mathrm{C}=\mathrm{O}), 177.9(\mathrm{C}=\mathrm{S}) . \mathrm{M}^{+\bullet}: 340(24)$; 338(64) Calcd 338.0856; Obsd 338.0860. Other ions $\mathrm{m} / \mathrm{z}$ (\%): 305(5.5), 292(24), 265(6), 212(33), 171(24), 169/73.5), 140 (18), 138(11.5), 127(19.5), 111(24), 96(100), 95(18), 79(21), 75(13), 68(57), 67(19), 41(13)

Ethyl (1R,3S,4S)-2-(benzylcarbamoyl)-2-azabicyclo[2.2.1]heptane-3-carboxylate (8). White crystals, mp: $92-94{ }^{\circ} \mathrm{C}$ (n-hexane/EtOAc), yield $0.61 \mathrm{~g},(69 \%) ;[\alpha]_{D}^{25}=-82.6(\mathrm{c} 0.5, \mathrm{EtOH}){ }^{1} \mathrm{H}$ NMR (DMSO-d $)_{6} \delta(\mathrm{ppm}): 1.18\left(3 \mathrm{H}, \mathrm{t}, J=7.2 \mathrm{~Hz}, \mathrm{OCH}_{2} \mathrm{CH}_{3}\right), 1.31(1 \mathrm{H}, \mathrm{brd}, J=9.6 \mathrm{~Hz}, \mathrm{H}-7)$, 1.43 (1H, m, H-5), 1.52-1.61 (2H, m, H-6), 1.69 (1H, m, H-5), 1.74 (1H, brm, H-7), $2.58(1 \mathrm{H}$, brs, H-4), $3.78\left(1 \mathrm{H}\right.$, brs, H-3), 4.01-4.11 (2H, m, $\left.\mathrm{OCH}_{2} \mathrm{CH}_{3}\right), 4.16(1 \mathrm{H}, \mathrm{dd}, J=15.5,5.7 \mathrm{~Hz}$, $\left.\mathrm{NCH}_{2}\right), 4.26-4.30\left(2 \mathrm{H}, \mathrm{m}, \mathrm{H}-1, \mathrm{NCH}_{2}\right), 6.96(1 \mathrm{H}, \mathrm{brs}, \mathrm{NH}), 7.20(1 \mathrm{H}, \mathrm{m}, p-\mathrm{Ar}), 7.24(2 \mathrm{H}, \mathrm{m}, o-$ Ar), 7.30 (2H, m, m-Ar). ${ }^{13} \mathrm{C}$ NMR (DMSO-d 6$) \delta(p p m): 14.0\left(\mathrm{OCH}_{2} \mathrm{CH}_{3}\right), 27.3(\mathrm{C}-5), 29.7(\mathrm{C}-$ 6), 35.0 (C-7), 41.2 (C-4), $43.0\left(\mathrm{NCH}_{2}\right), 55.7(\mathrm{C}-1), 60.0\left(\mathrm{OCH}_{2} \mathrm{CH}_{3}\right), 63.7$ (C-3), 126.3 (p-Ar), 126.7 (o-Ar), 128.0 (m-Ar), 140.9 (i-Ar), 155.8 (NH-C=O), 170.9 (O-C=O). $\mathrm{M}^{+\bullet}(22)$ $\mathrm{C}_{17} \mathrm{H}_{22} \mathrm{~N}_{2} \mathrm{O}_{3}{ }^{+\bullet}$ Calcd 302.1630 Obsd 302.1639 Other ions $\mathrm{m} / \mathrm{z}(\%): 256(38), 229(17), 228(11)$, 106(12), 96(100), 91(58), 68(44), 67(22), 65(11), 54(11), 41(12)

\section{General procedure of thiohydantoines 7a-d and hydantoine 9}

Compound 6a-d or $8(2.5 \mathrm{mmol})$ was refluxed in $25 \mathrm{~mL}$ EtOH containing $20 \%$ dry $\mathrm{HCl}$ for $5 \mathrm{~h}$. The reaction mixture was evaporated, diethyl ether was added, and the crystalline products 7c, $\mathbf{d}$ were filtered off and recrystallized. The epimers of $\mathbf{7 a}$ and $\mathbf{7 b}$ were separated by column chromatography ( $n$-hexane/EtOAc 5:1).

\section{5,8,8a-Hexahydro-2-ethyl-3-thioxo-5,8-methanoimidazo[1,5-a]pyridine-1(5H)-one (7a).}

(5S,8R,8aR)-7a (major epimer). oil (EtOAc), yield $0.21 \mathrm{~g},(41 \%) ;[\alpha]_{D}^{25}=+109.0$ (c 0.5 , $\mathrm{MeOH}){ }^{1} \mathrm{H}$ NMR (DMSO-d 6 ) $\delta(\mathrm{ppm}): 1.09\left(3 \mathrm{H}, \mathrm{t}, J=7.1 \mathrm{~Hz}, \mathrm{NCH}_{2} \mathrm{CH}_{3}\right), 1.10$ (1H, brm, H9syn), 1.32 (1H, brd, J=10.6 Hz, H-9anti), 1.64-1.72 (3H, m, H-7, H-7, H-6), 1.80 (1H, m, H-6), 2.81 (1H, brs, H-8), $3.68\left(2 \mathrm{H}, \mathrm{q}, J=7.2 \mathrm{~Hz}, \mathrm{NCH}_{2}\right), 3.95(1 \mathrm{H}, \mathrm{s}, \mathrm{H}-8 \mathrm{a}), 4.64(1 \mathrm{H}, \mathrm{brd}, J=3.5$ $\mathrm{Hz}, \mathrm{H}-5) .{ }^{13} \mathrm{C}$ NMR (DMSO-d 6 ) $\delta$ (ppm): $12.3\left(\mathrm{NCH}_{2} \mathrm{CH}_{3}\right), 26.4$ (C-6), 28.3 (C-7), $34.8(\mathrm{C}-9)$, 
$36.3\left(\mathrm{NCH}_{2}\right), 39.1$ (C-8), 65.2 (C-5), 67.3 (C-8a), 174.4 (C-1), 192.3 (C-3). M M $^{+\bullet}(100)$ $\mathrm{C}_{10} \mathrm{H}_{14} \mathrm{~N}_{2} \mathrm{OS}^{+\bullet}$ Calcd 210.0827 Obsd 210.0836 Other ions $\mathrm{m} / \mathrm{z}(\%)$ : 144(11), 141(27), 96(12), 95(10), 68(24), 67(20), 54(14), 41(11)

(5S,8R,8aS)-7a (minor epimer). White crystals, mp 62-63 ${ }^{\circ} \mathrm{C}$, yield $57 \mathrm{mg},(11 \%) ;[\alpha]_{D}^{25}=$ $+100.1(\mathrm{c}, 0.5 \mathrm{MeOH})^{1} \mathrm{H}$ NMR (DMSO-d 6 ) $\delta(\mathrm{ppm}): 0.97$ (1H, m, H-7endo), 1.10 (3H, t, J = 7.1 $\left.\mathrm{Hz}, \mathrm{NCH}_{2} \mathrm{CH}_{3}\right), 1.53$ (1H, m, H-6exo), 1.64 (1H, m, H-7exo), 1.80 (1H, m, H-9anti), 2.05-2.11 (2H, m, H-6endo, H-9), 2.85 (1H, brs, H-8), 3.63-3.73 (2H, m, NCH $), 4.36$ (1H, brs, H-5), 4.54 $(1 \mathrm{H}, \mathrm{dd}, J=3.6,1.4 \mathrm{~Hz}, \mathrm{H}-8 \mathrm{a}) .{ }^{13} \mathrm{C} \mathrm{NMR}\left(\mathrm{DMSO}_{6}\right) \delta(\mathrm{ppm}): 12.6\left(\mathrm{NCH}_{2} \mathrm{CH}_{3}\right), 21.3(\mathrm{C}-7)$, 27.2 (C-6), $36.0\left(\mathrm{NCH}_{2}\right), 37.6$ (C-8), 39.7 (C-9), 61.9 (C-5), 70.4 (C-8a), 172.9 (C-1), 187.8 (C3). $\mathrm{M}^{+\bullet}(56) \mathrm{C}_{10} \mathrm{H}_{14} \mathrm{~N}_{2} \mathrm{OS}^{+\bullet}$ Calcd 210.0827 Obsd 210.0830 Other ions $\mathrm{m} / \mathrm{z}(\%)$ : 144(100), 141(6), 96(5), 68(15), 67(16), 41(8)

\section{5,8,8a-Hexahydro-2-(4-methoxyphenyl)-3-thioxo-5,8-methanoimidazo[1,5-a]pyridine-}

\section{1(5H)-one (7b).}

(5S,8R,8aR)-7b (major epimer). White crystals, mp 183-184 ${ }^{\circ} \mathrm{C}$ (EtOAc), yield $0.42 \mathrm{~g}$, (58 $\%) ;[\alpha]_{D}^{25}=+63.4$ (c 0.5, EtOH) ${ }^{1} \mathrm{H}$ NMR (DMSO-d $) \delta(\mathrm{ppm}): 1.38-1.44$ (2H, m, H-9syn, H9anti), 1.69-1.76 (3H, m, H-7, H-7, H-6), 1.85 (1H, m, H-6), 2.91 (1H, brs, H-8), 3.80 (3H, s, p$\left.\mathrm{OCH}_{3}\right), 4.13(1 \mathrm{H}, \mathrm{s}, \mathrm{H}-8 \mathrm{a}), 4.72(1 \mathrm{H}, \mathrm{brd}, J=3.6 \mathrm{~Hz}, \mathrm{H}-5), 7.02(2 \mathrm{H}, \mathrm{m}, m-\mathrm{Ar}), 7.19$ (2H, m, oAr). ${ }^{13} \mathrm{C}$ NMR (DMSO-d 6 ) $\delta$ (ppm): 26.4 (C-6), 28.3 (C-7), 35.3 (C-9), 39.4 (C-8), 55.3 (p$\mathrm{OCH}_{3}$ ), 65.5 (C-5), 67.7 (C-8a), 114.0 (m-Ar), 126.2 (i-Ar), 129.5 (o-Ar), 159.2 (p-Ar), 174.2 (C-1), $192.6(\mathrm{C}-3) \cdot \mathrm{M}^{+\bullet}(91) \mathrm{C}_{15} \mathrm{H}_{15} \mathrm{~N}_{2} \mathrm{O}_{2} \mathrm{~S}^{+\bullet}$ Calcd 288.0932 Obsd 288.0943 Other ions $\mathrm{m} / \mathrm{z}$ (\%): 255(10), 222(5), 166(11), 165(100), 150(17), 149(15), 134(13), 133(6), 122(9), 67(8)

(5S,8R,8aS)-7b (minor epimer). White crystals, mp 105-107 ${ }^{\circ} \mathrm{C}$ (EtOAc), yield $86 \mathrm{mg},(12 \%)$; $[\alpha]_{D}^{25}=-57.0(\mathrm{c} 0.5, \mathrm{EtOH}){ }^{1} \mathrm{H}$ NMR $\left(\right.$ DMSO-d $\left._{6}\right) \delta(\mathrm{ppm}) 1.25(1 \mathrm{H}, \mathrm{m}, \mathrm{H}-7$ endo $), 1.60(1 \mathrm{H}, \mathrm{m}$, H-6ехо), 1.73 (1H, m, H-7exo), 1.85 (1H, m, H-9anti), 2.15 (1H, m, H-9syn), 2.25 (1H, m, H6endo), $2.92(1 \mathrm{H}, \mathrm{m}, \mathrm{H}-8), 3.80\left(3 \mathrm{H}, \mathrm{s}, p-\mathrm{OCH}_{3}\right), 4.43(1 \mathrm{H}, \mathrm{brs}, \mathrm{H}-5), 4.72(1 \mathrm{H}, \mathrm{dd}, J=3.6,1.4$ $\mathrm{Hz}, \mathrm{H}-8 \mathrm{a}), 7.02$ (2H, m, m-Ar), 7.17 (2H, m, o-Ar). ${ }^{13} \mathrm{C} \mathrm{NMR}\left(\mathrm{DMSO}-\mathrm{d}_{6}\right) \delta$ (ppm): 21.5 (C-7), 27.4 (C-6), 37.8 (C-8), 39.9 (C-9), $55.3\left(p-\mathrm{OCH}_{3}\right), 62.3$ (C-5), 70.8 (C-8a), 114.0 (m-Ar), 126.0 (i-Ar), 129.6 (o-Ar), 159.2 (p-Ar), 172.8 (C-1), 188.1 (C-3). $\mathrm{M}^{+\bullet}(76) \mathrm{C}_{15} \mathrm{H}_{15} \mathrm{~N}_{2} \mathrm{O}_{2} \mathrm{~S}^{+\bullet}$ Calcd 288.0932 Obsd 288.0944 Other ions $\mathrm{m} / \mathrm{z}(\%)$ : 255(3) 222(100), 166(8), 165(54), 150(17), 149(12.5), 134(12), 133(10), 122(10), 67(10)

(5S,8R,8aR)-5,8,8a-Hexahydro-2-(3-methoxyphenyl)-3-thioxo-5,8-methanoimidazo[1,5a]pyridine-1(5H)-one (7c). White crystals, mp 126-127 ${ }^{\circ} \mathrm{C}$ (EtOAc), yield $\left(0.53 \mathrm{~g},(73 \%) ;[\alpha]_{D}^{25}\right.$ $=+42.6(\mathrm{c} 0.5, \mathrm{MeOH}){ }^{1} \mathrm{H}$ NMR $\left(\mathrm{DMSO}_{\mathrm{d}}\right) \delta(\mathrm{ppm}):$ ): $1.40(1 \mathrm{H}, \mathrm{brd}, J=10.6 \mathrm{~Hz}, \mathrm{H}-9 a n t i)$, 1.46 (1H, m, H-9syn), 1.69-1.76 (3H, m, H-7, H-7, H-6), 1.85 (1H, m, H-6), 2.92 (1H, brs, H-8), $3.76\left(3 \mathrm{H}, \mathrm{s}, m-\mathrm{OCH}_{3}\right), 4.13(1 \mathrm{H}, \mathrm{s}, \mathrm{H}-8 \mathrm{a}), 4.73(1 \mathrm{H}, \mathrm{br} \mathrm{d}, J=3.4 \mathrm{~Hz}, \mathrm{H}-5), 6.84\left(1 \mathrm{H}, \mathrm{m}, o^{\prime}-\mathrm{Ar}\right)$, $6.89(1 \mathrm{H}, \mathrm{m}, o-\mathrm{Ar}), 7.02(1 \mathrm{H}, \mathrm{m}, p-\mathrm{Ar}), 7.39\left(1 \mathrm{H}, \mathrm{t}, J=8.1 \mathrm{~Hz}, m^{\prime}-\mathrm{Ar}\right) .{ }^{13} \mathrm{C}$ NMR $\left(\mathrm{DMSO}-\mathrm{d}_{6}\right) \delta$ (ppm): 26.4 (C-6), 28.3 (C-7), 35.3 (C-9), 38.9-39.9 (C-8, under DMSO), 55.3 (m-OCH $), 65.6$ (C-5), 67.8 (C-8a), 114.2 (o-Ar), 114.3 (p-Ar), 120.4 (o'-Ar), 129.5 (m'-Ar), 134.7 (i-Ar), 159.4 (m-Ar), 173.9 (C-1), $192.0(\mathrm{C}-3) . \mathrm{M}^{+\bullet}(100) \mathrm{C}_{15} \mathrm{H}_{16} \mathrm{~N}_{2} \mathrm{O}_{2} \mathrm{~S}_{2}{ }^{+\bullet}$ Calcd 288.0932 Obsd 288.0942 Other ions $\mathrm{m} / \mathrm{z}$ (\%): 287(6), 254(5), 222(9), 166(14), 166(11), 165(98), 95(20), 77(10), 67(10.5) 
(5S,8R,8aR)-5,8,8a-Hexahydro-2-(4-chlorophenyl)-3-thioxo-5,8-methanoimidazo[1,5a]pyridine-1(5H)-one (7d). White crystals, mp 155-157 ${ }^{\circ} \mathrm{C}\left(\right.$ EtOAc), yield $0.49 \mathrm{~g},(67 \%) ;[\alpha]_{D}^{25}$ $=+48.2(\mathrm{c} 0.5, \mathrm{MeOH}){ }^{1} \mathrm{H}$ NMR $\left(\mathrm{DMSO}_{-}\right) \delta(\mathrm{ppm}): 1.40(1 \mathrm{H}$, brd, $J=10.5 \mathrm{~Hz}, \mathrm{H}-9$ anti), 1.48 (1H, m, H-9syn), 1.70-1.76 (3H, m, H-7, H-7, H-6), 1.86 (1H, m, H-6), 2.92 (1H, brs, H-8), 4.15 $(1 \mathrm{H}, \mathrm{s}, \mathrm{H}-8 \mathrm{a}), 4.73(1 \mathrm{H}$, brd, $J=3.2 \mathrm{~Hz}, \mathrm{H}-5), 7.36(2 \mathrm{H}, \mathrm{m}, \mathrm{o}-\mathrm{Ar}), 7.57(2 \mathrm{H}, \mathrm{m}, m-\mathrm{Ar}) .{ }^{13} \mathrm{C}$ NMR $\left(\mathrm{DMSO}_{6}\right.$ ) $\delta$ (ppm): 26.4 (C-6), 28.3 (C-7), 35.4 (C-9), 38.9-39.9 (C-8, under DMSO), 65.6 (C5), 67.9 (C-8a), 128.9 (m-Ar), 130.3 (o-Ar), 132.5 (p-Ar), 133.4 (i-Ar), 173.8 (C-1), 191.6 (C-3). $\mathrm{M}^{+\bullet}(100) \mathrm{C}_{15} \mathrm{H}_{16} \mathrm{~N}_{2} \mathrm{O}_{2} \mathrm{~S}_{2}^{+\bullet}$ Calcd 292.0437 Obsd 292.0444 Other ions $\mathrm{m} / \mathrm{z}$ (\%): 229(12), 226(10), 171(29), 169(79), 111(12.5), 95(45.5), 68(17), 67(19), 54(10), 41(10)

(5R,8S,8aS)-5,8,8a-tetrahydro-2-benzyl-5,8-methanoimidazo[1,5-a]pyridine-1,3(2H,5H)dione (9). White crystals, mp 85-86 ${ }^{\circ} \mathrm{C}$ (EtOAc), yield $0.47 \mathrm{~g},(73 \%) ;[\alpha]_{D}^{25}=-78.1$ (c 0.5 , $\mathrm{MeOH}){ }^{1} \mathrm{H}$ NMR (DMSO-d 6 ) $\delta$ (ppm): 1.07 (1H, m, H-9), 1.30 (1H, brd, J= 10.7 Hz, H-9), 1.501.58 (2H, m, H-6, H-7), 1.63 (1H, m, H-7), 1.70 (1H, m, H-6), 2.75 (1H, brd, J= 2.8 Hz, H-8), $3.82\left(1 \mathrm{H}\right.$, br s, H-8a), $4.22(1 \mathrm{H}$, brd, $J=\sim 2.4 \mathrm{~Hz}, \mathrm{H}-5), 4.51\left(1 \mathrm{H}, \mathrm{d}, J=15.2 \mathrm{~Hz}, \mathrm{NCH}_{2}\right), 4.54$ $\left(1 \mathrm{H}, \mathrm{d}, J=15.2 \mathrm{~Hz}, \mathrm{NCH}_{2}\right), 7.24(2 \mathrm{H}, \mathrm{m}, o-\mathrm{Ar}), 7.28(1 \mathrm{H}, \mathrm{m}, p-\mathrm{Ar}), 7.33(2 \mathrm{H}, \mathrm{m}, \mathrm{m}-\mathrm{Ar}) .{ }^{13} \mathrm{C}$ NMR (DMSO-d 6 ) $\delta$ (ppm): 27.0 (C-6), 27.7 (C-7), 34.5 (C-9), 38.8 (C-8), $41.8\left(\mathrm{NCH}_{2}\right), 60.4$ (C-5), 65.8 (C-8a), 127.3 (o-Ar), 127.5 (p-Ar), 128.5 (m-Ar), 136.2 (i-Ar), 163.2 (C-3), 173.9 (C1). $\mathrm{M}^{+\bullet}(100) \mathrm{C}_{15} \mathrm{H}_{16} \mathrm{~N}_{2} \mathrm{O}_{2}^{+\bullet}$ Calcd 256.1222 Obsd 256.1212 Other ions $\mathrm{m} / \mathrm{z}$ (\%): 228(22), 132(11), 96(18), 95(12), 91(57), 68(19), 678189, 54(14)

Ethyl (1R,3S,4S)-2-(4,5-dihydro-thiazol-2-yl)-2-azabicyclo[2.2.1]heptane-3-carboxylate (10). It was prepared from base $(+)-5(0.5 \mathrm{~g}, 2.96 \mathrm{mmol})$ in $20 \mathrm{~mL}$ with one equivalent of the chloroethylisothiocyanate $^{33}$ as described for 6. The oily product was purified by column chromatography. Oil, (toluene: methanol $=4: 1$ ), yield $0.64 \mathrm{~g},(85 \%) ;[\alpha]_{D}^{25}=-193.1$ (c 1 , $\mathrm{MeOH}){ }^{1} \mathrm{H}$ NMR (DMSO-d 6$) \delta(\mathrm{ppm}): 1.22,\left(3 \mathrm{H}, \mathrm{t}, J=7.1, \mathrm{OCH}_{2} \mathrm{CH}_{3}\right), 1.52(1 \mathrm{H}, \mathrm{brd}, J=11.0$, H-7), 1.62 (1H, brm, H-5), 1.65-1.70 (2H, brm, H-6), 1.75 (1H, brm, H-7), 1.77 (1H, brm, H-5), $2.86(1 \mathrm{H}$, brd, $J=2.8, \mathrm{H}-4), 3.58\left(2 \mathrm{H}\right.$, brm, $\left.\mathrm{CH}_{2} \mathrm{~S}\right), 3.92\left(2 \mathrm{H}\right.$, brt, $\left.J=7.3 \mathrm{~Hz}, \mathrm{NCH}_{2}\right), 4.12(1 \mathrm{H}$, brs, H-1), 4.17 (3H, q, $\left.J=7.1, \mathrm{OCH}_{2} \mathrm{CH}_{3}\right), 4.21$ (1H, brs, H-3). ${ }^{13} \mathrm{C}$ NMR $\left(\mathrm{DMSO}-\mathrm{d}_{6}\right) \delta(\mathrm{ppm})$ : $13.8\left(\mathrm{OCH}_{2} \mathrm{CH}_{3}\right), 25.8(\mathrm{C}-5), 28.9(\mathrm{C}-6), 32.5\left(\mathrm{CH}_{2} \mathrm{~S}\right), 35.1(\mathrm{C}-7), 42.0(\mathrm{C}-4), 50.8\left(\mathrm{CH}_{2} \mathrm{~N}\right), 61.4$ $\left(\mathrm{OCH}_{2} \mathrm{CH}_{3}, 68.0\right.$ and $68.3(\mathrm{C}-1$ and $\mathrm{C}-3), 176.8(\mathrm{C}=\mathrm{O}) . \mathrm{M}^{+\bullet}(27) \mathrm{C}_{12} \mathrm{H}_{18} \mathrm{~N}_{2} \mathrm{O}_{2} \mathrm{~S}^{+\bullet}$ Calcd 254.1089 Obsd 254.1083 Other ions $\mathrm{m} / \mathrm{z}(\%)$ : 182(21), 181(100), 153(62)

(1S,3R,4R)-3-Hydroxymethyl-2-azabicyclo[2.2.1]heptane (12). To a slurry of $\mathrm{LiAlH}_{4}(1.5 \mathrm{~g}$, $39.55 \mathrm{mmol})$ in $50 \mathrm{~mL}$ of dry THF, amino ester base (-)-5 (4.25 g, $25 \mathrm{mmol})$ in $20 \mathrm{~mL}$ of THF was added dropwise at room temperature. After stirring one hour, the mixture was decomposed with $2 \mathrm{~mL}$ of water under ice cooling. The inorganic material was filtered off and washed with THF. After drying and evaporation, the resulting oil was crystallized from $n$-hexane and recrystallized. White crystals, $\mathrm{mp} 126-127{ }^{\circ} \mathrm{C}\left(\mathrm{iPr}_{2} \mathrm{O}\right)$ yield $\left(1.8 \mathrm{~g}, 57 \%\right.$; $[\alpha]_{D}^{25}=-61.9$ (c 0.5 , $\mathrm{MeOH})$ Lit: $[\alpha]_{D}^{25}=-62.9\left(\mathrm{c} 1, \mathrm{CHCl}_{3}\right)^{28}{ }^{1} \mathrm{H}$ NMR $\left(\mathrm{DMSO}_{6}\right) \delta(\mathrm{ppm}): 1.39,(1 \mathrm{H}, \mathrm{td}, J=9.0$, $1.9 \mathrm{~Hz}, \mathrm{H}-5)$,1.47 (1H, d $J=10.9 \mathrm{~Hz}, \mathrm{H}-7), 1.61(1 \mathrm{H}, \mathrm{dd}, J=3.3, J=12.2 \mathrm{~Hz}, \mathrm{H}-6), 1.66(1 \mathrm{H}$, dd, $J=3.5, J=12.2 \mathrm{~Hz}, \mathrm{H}-6), 1.75$ (2H, m, H-5, H-7), 2.41 (1H, brs, H-4), 3.16 (1H, dd, $J=5.5$, 
$J=7.9 \mathrm{~Hz}, \mathrm{H}-3), 3.39\left(1 \mathrm{H}, \mathrm{dd}, J=.2, J=11.6 \mathrm{~Hz}, \mathrm{CH}_{2} \mathrm{OH}\right), 3.66(1 \mathrm{H}, \mathrm{dd}, J=5.5, J=11.6 \mathrm{~Hz}$, $\left.\mathrm{CH}_{2} \mathrm{OH}\right), 3.89$ (1H, brs, H-1), $8.70\left(1 \mathrm{H}\right.$, brs, NH). ${ }^{13} \mathrm{C}$ NMR (DMSO-d $) \delta$ (ppm): $25.0(\mathrm{C}-6)$, 27.1 (C-5), 34.4 (C-7), 37.0 (C-4), 56.8 (C-1), $60.2\left(\mathrm{CH}_{2} \mathrm{OH}\right), 64.2(\mathrm{C}-3) . \mathrm{M}^{+\bullet}(3.5) \mathrm{C}_{7} \mathrm{H}_{13} \mathrm{NO}^{+\bullet}$ Calcd 127.0997 Obsd 127.0991 Other ions $m / z$ (\%): 95(84), 68(100), 67(11), 41(16)

(1S,3R,4R)-1-(4-Chlorophenyl)-3-(3-hydroxymethyl-bicyclo[2.2.1]hept-2-yl thiourea (13). It was prepared from amino alcohol $12(0.4 \mathrm{~g}, 3.14 \mathrm{mmol}$ in $20 \mathrm{~mL})$, with $p$ chlorophenylisothiocyanate as described for 6. White crystals, mp 189-190 ${ }^{\circ} \mathrm{C}$ (EtOAc) yield $0.61 \mathrm{~g},(66 \%) ;[\alpha]_{D}^{25}=+198.5(\mathrm{c} 0.5, \mathrm{MeOH}){ }^{1} \mathrm{H}$ NMR (DMSO-d $) \delta(\mathrm{ppm}): 1.2-2.0(6 \mathrm{H}, \mathrm{m}, \mathrm{H}-$ 5, H-6, H-7), 3.17 (1H, d J = 5.0, Hz, H-4), 3.61 (1H, m, H-3), 3.61-3.66 (2H, m, $\left.\mathrm{CH}_{2} \mathrm{OH}\right), 4.83$ (1H, brs, H-1), $7.33(2 \mathrm{H}, \mathrm{m}, m-\mathrm{Ar}), 7.49(2 \mathrm{H}, \mathrm{brd}, J=7.6 \mathrm{~Hz}, o-\mathrm{Ar}) .{ }^{13} \mathrm{C}$ NMR $\left(\mathrm{DMSO}-\mathrm{d}_{6}\right) \delta$ (ppm): 27.1 (C-6), 28.7 (C-5), 35.0 (C-7), 41.1 (C-4), 62.7 (C-1), $65.3\left(\mathrm{CH}_{2} \mathrm{OH}\right), 70.0$ (C-3), 125.2 (o-Ar), 127.9 (p-Ar), 128.4 (m-Ar), 139.9 (i-Ar), 179.0 (C=S). $\mathrm{M}^{+\bullet}(19) \mathrm{C}_{14} \mathrm{H}_{17} \mathrm{~N}_{2} \mathrm{OSCl}^{+\bullet}$ Calcd 296.0750 Obsd 296.0756 Other ions $\mathrm{m} / \mathrm{z}(\%)$ : 278(12), 171(38), 169(100), 127(33), 113(11), 111(39), 96(53), 75(21), 68(63), 67(18)

(5S,8R,8aR)-3-(4-Chlorophenylimino)-perhydro-5,8-methanothiazolo[3,4-a]pyridine (14). It was prepared from $13(2 \mathrm{mmol})$ as described for tiohydantoines 7. White crystals, mp 184-185 ${ }^{\circ} \mathrm{C}(\mathrm{EtOH})$ yield $0.3 \mathrm{~g},(55 \%) ;[\alpha]_{D}^{25}=+394.0(\mathrm{c} 0.5, \mathrm{MeOH}){ }^{1} \mathrm{H}$ NMR $\left(\mathrm{DMSO}^{-\mathrm{d}_{6}}\right) \delta(\mathrm{ppm})$ : 1.50 (2H, brm, H-6, H-9), 1.63 (1H, brm, H-6), 1.70-1.75 (2H, m, H-7), 1.81 (1H, brm, H-9), $2.59(1 \mathrm{H}$, brs, H-8), 3.23 (1H, brt, $J=12.1 \mathrm{~Hz}, \mathrm{H}-1), 3.62(1 \mathrm{H}$, brdd, $J=6.5,12.1 \mathrm{~Hz}, \mathrm{H}-1), 4.06$ (1H, brm, H-8a), 4.80 (1H, brs, H-5), 7.33, (2H, brm, o-Ar), 7.59 (2H, brd, $J=8.0 \mathrm{~Hz}, m-\mathrm{Ar})$. ${ }^{13} \mathrm{C}$ NMR (DMSO-d $) \delta$ (ppm): 26.8 (C-7), 27.1 (C-6), 37.0 (C-9), 37.5 (C-1), 39.9 (C-8), 64.3 (C-5) 71.6 (C-8a), 125.4 (o-Ar), 129.3 (m-Ar), 131.1 (p-Ar), 139.0 (i-Ar), 170.0 (C-3). M ${ }^{+\bullet}(100)$ $\mathrm{C}_{14} \mathrm{H}_{15} \mathrm{~N}_{2} \mathrm{SCl}^{+\bullet}$ Calcd 278.0644 Obsd 278.0644 Other ions $\mathrm{m} / \mathrm{z}(\%):$ 277(28), 211(10), 169(15), 41(10)

3-(4-Nitrophenyl)-perhydro-5,8-methanooxazolo[3,4-a]pyridine (15). To a solution of the amino alcohol 12 (300 mg, $2.36 \mathrm{mmol})$ in $20 \mathrm{~mL}$ methanol, p-nitrobenzaldehyde (389 mg, 2.36 mmol) was added, and the mixture was refluxed for 10 hours. The solvent was then evaporated off. The product proved to be a mixture of epimers, of which the two epimers could be separated by crystallization from $n$-hexane.

(3S,5S,8R,8aR)-15 (major epimer). Yellow crystals, mp $101-102{ }^{\circ} \mathrm{C}$ (n-hexane) yield $0.25 \mathrm{~g}$, $(41 \%) ;[\alpha]_{D}^{25}=-86,7(\mathrm{c} 0.5, \mathrm{MeOH}){ }^{1} \mathrm{H}$ NMR $\left(\mathrm{DMSO}_{6}\right) \delta(\mathrm{ppm}): 1.10(1 \mathrm{H}, \mathrm{brd}, J=9.8 \mathrm{~Hz}$, H-9anti), 1.20-1.60 (4H, m, H-7, H-6), 1.67 (1H, dm, J = 9.8 Hz, H-9syn), 2.30 (1H, brs, H-8), 3.14 (1H, dd, $J=4.8,7.4 \mathrm{~Hz}, \mathrm{H}-8 \mathrm{a}), 3.42$ (1H, brs, H-5), 3.47 (1H, dd, $J=4.8,8.9 \mathrm{~Hz}, \mathrm{H}-1$ ), 3.69 (1H, dd, $J=7.4,8.9 \mathrm{~Hz}, \mathrm{H}-1), 5.54$ (1H, brs, H-3), 7.68, (2H, m, o-Ar), 8.19 (2H, m, m-Ar) ${ }^{13} \mathrm{C}$ NMR (DMSO-d $)_{6} \delta$ (ppm): 26.6 (C-7), 30.1 (C-6), 31.9 (C-9), 40.6 (C-8), 62.0 (C-5), 67.7 (C-8a), 69.3 (C-1), 95.7 (C-3), 123.1 (m-Ar), 127.8 (o-Ar), 147.0 (p-Ar), 149.2 (i-Ar).

(3R,5S,8R,8aR)-15 (minor epimer). Yellow crystals, mp 94-195 ${ }^{\circ} \mathrm{C}$ ( $n$-hexane) yield $0.21 \mathrm{~g}$, (35 $\%) ;[\alpha]_{D}^{25}=-80,2(\mathrm{c} 0.5, \mathrm{MeOH}){ }^{1} \mathrm{H}$ NMR (DMSO-d 6 ) $\delta$ (ppm): ): 0.89 (1H, brd, $J=9.5 \mathrm{~Hz}, \mathrm{H}-$ 9anti), 1.21-1.32 (3H, m, H-7, H-6, H-6), 1.39 (1H, m, H-7), 1.47 (1H, m, H-9syn), 2.36 (1H, brd, $J=4.0 \mathrm{~Hz}, \mathrm{H}-8), 2.61$ (1H, brm, H-5), 3.28 (1H, dd, $J=7.7,2.9 \mathrm{~Hz}, \mathrm{H}-8 \mathrm{a}), 3.70$ (1H, dd, $J$ 
= 8.8, 3.0 Hz, H-1), $3.75(1 \mathrm{H}, \mathrm{dd}, J=8.8,7.7 \mathrm{~Hz}, \mathrm{H}-1), 5.34$ (1H, brs, H-3), 7.70 (2H, m, o-Ar), 8.29 (2H, m, m-Ar). ${ }^{13} \mathrm{C}$ NMR (DMSO-d 6 ) $\delta$ (ppm): 26.3 (C-7), 30.4 (C-6), 33.5 (C-9), 41.4 (C8), 56.3 (C-5), 67.9 (C-8a), 69.6 (C-1), 94.2 (C-3), 123.4 (m-Ar), 128.0 (o-Ar), 143.6 (i-Ar), 147.2 (p-Ar). $\mathrm{M}^{+\bullet}(100) \mathrm{C}_{14} \mathrm{H}_{16} \mathrm{~N}_{2} \mathrm{O}_{3}{ }^{+\bullet}$ Calcd 260.1161 Obsd 260.1173 Other ions $\mathrm{m} / \mathrm{z}(\%)$ : 259(15), 231(27), 230(92), 202(21), 138(32), 109(30), 108(38), 94(27), 89(1), 81(36), 80(33), 77(15), 68(27), 67(39), 66(20), 55(12), 54(43), 53(15), 42(11), 41(37), 39(19)

\section{Acknowledgements}

We are grateful to the Hungarian Research Foundation (OTKA No. K75433 and T049407) for financial support.

\section{References}

1. Coppola, G. M.; Schuster, H. F. Asymmetric Synthesis: Constitution of chiral molecules using amino acids; John Wiley \& Sons: New York, 1987.

2. Portevin, B.; Benoist, A.; Remond, G.; Herve, Y.; Vincent, M.; Lepagnol, J.; Nanteuil, G. J. Med. Chem. 1996, 39, 2379.

3. Bunch, L.; Liljefors, T.; Greenwood, J. R.; Frydenvang, K.; Bräuner-Osborne, H.; Krogsgaard-Larsen, P. Madsen, U. J. Org. Chem. 2003, 68, 1489.

4. Trabocchi, A.; Scarpi, D.; Guarna, A. Amino acids 2008, 34, 1.

5. Mellor, J. M.; Richards, N. G. J.; Sargood, K. J.; Anderson, D. W.; Chamberlain S. ].; Davies, D. E. Tetrahedron Lett. 1995, 36, 6765.

6. Jäger, M.; Polborn, K.; Steglich, W. Tetrahedron Lett. 1995, 36, 861.

7. Venkatraman, S.; Njoroge, F. G.; Wu, W.; Girijavallabhan, V.; Prongay, A. J.; Butkiewicz, N.; Pichardo, J. Bioorg. Med. Chem. Lett. 2006, 16, 1628.

8. Brandt, P.; Andersson, P. G. Synlett 2000, 1092.

9. Ekegren, J. K.; Modin, S. A.; Alonso, D. A.; Andersson, P. G. Tetrahedron: Asymmetry 2002, 13, 447.

10. Altomare, C.; Trapani, G.; Latrofa, A.; Serra, M.; Sanna, E.; Biggio, G.; Liso, G. Eur. J. Pharm. Sci. 2003, 20, 17.

11. Limburg, D. C.; Thomas, IV. B. E.; Li, J. H.; Fuller, M.; Spicer, D.; Chen, Y.; Guo, H.; Steiner, J.; P.; Hamilton, G. S.; Wu, Y. Q. Bioorg. Med. Chem. Lett. 2003, 13, 3867.

12. Alvarez de Cienfuegos, L.; Langlois, N. Tetrahedron: Asymmetry 2006, 17, 1863.

13. Hill, T. J.; Kocis, P.; Moloney, M. G. Tetrahedron Lett. 2006, 47, 1461.

14. Langlois, N.; Le Nguyen, B. K.; Retailleau, P.; Tarnus, C.; Salomon, E. Tetrahedron: Asymmetry 2006, 17, 53. 
15. Penhoat, M.; Leleu, S.; Dupas, G.; Papamicaël, C.; Marsais, F.; Levacher, V. Tetrahedron Lett. 2005, 46, 8385.

16. Endo, A.; Danishefsky, S. J. J. Am. Chem. Soc. 2005, 127, 8298.

17. Nakano, H.; Takahashi, K.; Fujita, R. Tetrahedron: Asymmetry 2005, 16, 2133.

18. Langlois, N.; Le Nguyen, B. K. J. Org. Chem. 2004, 69, 7558.

19. Nakano, H.; Takahashi, K.; Okuyama, Y.; Senoo, C.; Tsugawa, N.; Suzuki, Y.; Fujita, R.; Sasaki, K.; Kabuto, C. J. Org. Chem. 2004, 69, 7092.

20. Okuyama, Y.; Nakano, H.; Hongo, H. Tetrahedron: Asymmetry: 2000, 11, 1193.

21. Pihno, P.; Andersson, G. Chem. Commun. 1999, 597.

22. Tararov, V. I.; Kadyrov, R.; Kadyrova, Z.; Dubrovina, N.; Börner, A. Tetrahedron: Asymmetry 2002, 13, 25.

23. Bertlisson, S. K.; Södergen, M. J.; Andersson, P. G. J. Org. Chem. 2002, 67, 1567.

24. Hurthouse, M.; Abdul Malik, K. M.; Hibbs, D.; Roberts, S.; Seago, A.; Sik, V.; Storer, R. J. J. Chem. Soc., Perkin Trans. 1 1995, 19, 2419.

25. Dyatkin, A. B.; Hoekstra, W. J.; Hlasta, D. J.; Andrade-Gordon, P.; Garavilla, L.; Demarest, K. T.; Gunnet, J. W.; Hageman, W.; Look, R.; Maryanoff, B. E. Bioorg. Med. Chem. Lett. 2002, 12, 3081.

26. Fülöp, F.; Bernáth, G.; Pihlaja, K. Adv. Heterocyclic Chem. 1998, 69, 349.

27. Pihno, P.; Guijarro, D.; Andersson, G. Tetrahedron 1998, 44, 7897.

28. Alonso, D. A.; Guijarro, D.; Pihno, P.; Temme, O.; Andersson, P. G. J. Org. Chem. 1998, 63, 2749.

29. Salvati, M. E.; Balog, A.; Pickering, D. A.; Giese, S.; Fura, A.; Li, W.; Patel, R.; Hanson, R. L.; Mitt, T.; Roberge, J.; Corte, J. R.; Spergel, S. H.; Rampulla, R. A.; Misra, R.; Xiao, H.Y. WO 2003062241; Chem. Abstr. 2003, 139, 164784.

30. Balog, A.; Salvati, M.; Shan, W.; Marthur, A.; Leith, L. W.; Wei, D. D.; Attar, R. M.; Geng, J.; Rizzo, C. A.; Wang, C.; Krystek, S. R.; Tokarski, J. S.; Hunt, J. T.; Gottardis, M.; Weinmann, R. Bioorg. Med. Chem. Lett. 2004, 14, 6107.

31. Sun, C.; Robl, J. A.; Wang, T. C.; Huang, Y.; Kuhns, J. E.; Lupisella, J. A.; Beehler, B. C.; Golla, R.; Sleph, P. G.; Seethala, R.; Fura, A.; Krystek, S. R.; An, Y.; Malley, M. F.; Sack, J. S.; Salvati, M E.; Grover, G. J.; Ostrowski, J.; Hamann, L. G. J. Med. Chem. 2006, 49, 7596.

32. Salvati, M. E.; Balog, J. A., US 20010620; Chem. Abstr. 2003, 139, 53039.

33. Brintzinger, H. Pfannstiel, K. Koddebush, H. Chem. Ber. 1949. 82, 389. 